\title{
Lack of Efficacy of the Adenosine Reuptake Inhibitor Dipyridamole in the Treatment of Anxiety Disorders
}

\author{
Murray B. Stein, Bruce Black, Terry M. Brown and Thomas W. Uhde
}

\begin{abstract}
We administered dipyridamole, an adenosine reuptake inhibitor, to 12 outpatients with DSMIII-R anxiety disorders (2 patients with generalized anxiety disorder, 10 patients with panic disorder). Dipyridamole was administered at a flexible dose in a single-blinded fashion following a placebo washout phase and elimination of placebo responders. The mean duration of active treatment with dipyridamole was 46 days (range 21-88 days); the mean peak dose of dipyridamole was $202 \pm 55 \mathrm{mg} /$ day (range 100-300 mg/day). Symptom ratings were completed at regular intervals by the patient and by a research nurse unaware of the treatment condition. Clinically significant improvement in anxiety symptoms was not demonstrated. The implications of these findings for an adenosinergic dysfunction model of panic disorder are discussed.
\end{abstract}

Key Words: Dipyridamole, anxiety, adenosine, panic, pharmacotherapy

\section{Introduction}

Patients with anxiety disorders, particularly panic disorder, have been shown to be hypersensitive to the anxiogenic effects of caffeine (Boulenger et al 1984; Boulenger and Uhde 1982; Chamey et al 1985; Unde 1990). The psychostimulant effects of caffeine are widely believed to be mediated via its action as an adenosine antagonist (Boulenger et al 1982; Fredholm and Persson 1982; Gould et al 1984; Snyder and Sklar 1984; Uhde 1990). Adenosine is a major neuromodulator that acts at two different receptor subfamilies-the $A_{1}$ receptor, which inhibits adenylate cyclase through $G_{i}$, and the $A_{2}$ receptor, which stim-

From the Section on Anxiely and Affective Disonders, Biological Psychicisy Branch, Intramural Research Program. National Institute of Mental Health, National Instinutes of Health. Bethesda, Maryland.

Address reprint requests to Thomas W. Uhde, M.D.. Chief, Section on Anxiety and Affuctive Disorders, National institute of Mertal Health, Building 10 . Room 3S235, 9000 Rockvilte Pike, Bethesda, MD 20892.

Received June 9. 1992; revised January 18, 1993; accepted January 18, 1993. ulates adenylate cyclase through $\mathrm{G}_{8}$ (Barraco et al 1991); Bruns 1990; Linden 1991; Snyder 1985). Antagonism of adenosine receptors with caffeine (which competitively inhibits both $A_{1}$ and $A_{2}$ subtypes) and related methylxanthines has been demonstrated to result in increased anxietylike behaviors in several experimental paradigms in animals (Barraco et al 1983; Choi et al 1988; Coffin and Spealman 1987; Snyder et al 1981). These convergent observations have led to the hypothesis that patients with panic disorder, who exhibit unprovoked attacks of anxiety and marked caffeine sensitivity, may exhibit an abnormality in central nervous system (CNS) adenosinergic function (Boulenger et al 1987; Uhde 1990). This study was intended to expand on this theory by testing the corollary hypothesis that enhancing adenosinergic neurotransmission would be beneficial in the treatment of panic (and possibly other anxiety) disorder(s).

Dipyridamole is a vasodilator and antiplatelet agent that historically has found its major applications in the treat- 
ment of chronic angina and in the prevention of thromboembolic stroke. Dipyridamole is also an inhibitor of endothelial cell adenosine reuptake (Klabunde 1983). Its oral administration in humans leads to increased serum levels of adenosine (Sollevi et al 1984). We hypothesized that the administration of dipyridamole in patients with anxiety disorders would result in a reduction in anxiety via an augmentation of adenosinergic neurotransmission. There are no reports to date on the use of dipyridamole or other adenosinergically active comnounds for the treatment of anxiety states.

\section{Methods}

All patients were evaluated and treated as outpatients in an anxiety disorders research clinic. Patients were assessed prior to treatment using a moditied version of the SADS. LA diagnostic interview (Fyer et al 1985). All patients meeting DSM-III-R criteria for panic disorder, panic disorder with agoraphobia, or generalized anxiety disorder were considered for inclusion. Subjects with other current non-anxiely Axis I psychiatric disorders, including major depression, were excluded. All subjects had complete physical examinations, electrocardicgrams, and standard blood and urine laboratory screening and were found to be free of medical illness. All subjects were instructed to be free of medications, caffeine, and alcohol for a minimum of 4 weeks prior to starting treatment.

Nine subjects were treated with placebo (mean \pm SD $36.7=22.7$ days; range 8-77 days), followed by a period of active dipyridamole treatment, followed by abrupt discontinuation of dipyridamnle and another period of placebo treatment (mean \pm SD $15.1 \pm 5.2$ days; range 7-24 days). Three additional subjects who had been medication free for at least 4 weeks did not receive placebo prior to treatment with dipyridamole, but they had been told that they might be treated with placebo and were unaware of iheir medication status. These two groups of subjects were combined for this analysis, yielding 12 subjects, 10 with panic disorder or panic disorder with agoraphobia and 2 with generalized anxiety disorder.

All subjects received placebo and dipyridamole in identical pink capsules. Subjects were aware that they might be treated with placebo or dipyridamole but were otherwise unaware of the treatment design. Dipyridamole treatment started at $20-40 \mathrm{mg} /$ day and was increased as tolerated to a maximum of $.300 \mathrm{mg} /$ day. Although the research psychiatrist was given optimal flexibility in the rate and timing of dosage increases to minimize potential side effects, every effort was made to achieve the maximum dose within 4 weeks of siarting active medication. Overall, the mean \pm SD duration of active treatment with dipyridamole was $46.2 \pm 21.2$ days (range 21-88 days); the mean \pm SD peak dose of dipyridamole was $202 \pm 54.8 \mathrm{mg} /$ day (range 100-300 mg/day).

Ratings were obtained every 2 weeks. Subjects completed the following self-ratings: the Beck Depression Inventory, the Spielberger State Anxiety Scale, and the Patient-Rated Anxiety Scale (of Sheehan). An experienced research nurse who was unaware of the treatment design and the subject's treatment status completed the following ratings: the Hamilton Rating Scale for Depression (21 items), the Zung Clinician-Rated Anxiety Scale, and the National Institute of Mental Health (Bunney-Hamburg) Global Anxiety Rating. The research nurse also recorded the subject's self-report of the number of panic attacks and limited-symptom attacks in the previous week and the percent of time (while awake) that the subject reported feeling anxious during the previous week. The same research nurse completed all clinician ratings for all subjects in this study.

For all 12 subjects, we compared ratings made immediateiy prior to the initiation of active treatment with dipyridamole (pretreatment ratings) and at the end of active treatment (treatment ratings), just prior to the abrupt discontinuation of dipyridamole, using paired $t$-tests, except in the case of panic attacks, where a nonparametric test (Wilcoxon rank-sum test) was used. For the nine subjects treated with placebo before and after treatment with dipyridamole, we also coinpared pretreatment, treatment, and posttreatment ratings (made at the end of placebo treatment) using one-factor repeated measures analysis of variance. All tests were two tailed.

\section{Results}

Results are shown in Table 1. Other than a modest reduction in the percent of time reported to be anxious, no statistically (or clinically) significant effects of dipyridamole could be demonstrated. Overall, only one of 12 patients was judged by the (nonblinded) clinician to be globally improved at the end of treatment with dipyridamole, a rate of improvement that is less favorable than reported for placebo response in most panic disorder studies (Ballenger et al 1988). At the end of active treatment, when placebo was abruptly substituted for dipyridamole, there was no evidence of clinical deterioration.

All subjects tolerated the treatment well. Complaints of side effects during active treatment were minimal (mild headache in two patients, nausea in three patients), and no subjects dronped out of the study because of treatmentemergent side effects.

\section{Discussion}

Our findings do not support the clinical utility of dipyridamole as a treatment for panic or generalized anxiety disorder. Although the possibility of a type II eñor cannot 
Table 1. Study Outcome Measures

\begin{tabular}{|c|c|c|c|c|c|c|c|c|}
\hline & \multirow{2}{*}{$\begin{array}{l}\text { Pretreatment } \\
\text { ratings } \\
\text { (mean } \pm \text { SD) }\end{array}$} & \multirow{2}{*}{$\begin{array}{c}\text { Treatment } \\
\text { ratings } \\
\text { (mean } \pm \mathrm{SD} \text { ) }\end{array}$} & \multirow{2}{*}{$\begin{array}{l}\text { Posttreatment } \\
\text { ratings } \\
\text { (mean } \pm \mathrm{SD} \text { ) }\end{array}$} & \multicolumn{2}{|c|}{$\begin{array}{l}\text { ANOVA }{ }^{a} \\
(n=9)\end{array}$} & \multicolumn{3}{|c|}{$\begin{array}{l}\text { Paired } t \text {-test } t^{b} \\
\qquad(n=12)\end{array}$} \\
\hline & & & & $F$ & $p$ value & $t$ & df & $p$ value \\
\hline \multicolumn{9}{|l|}{ Self-rated measures } \\
\hline $\begin{array}{l}\text { Beck Depression } \\
\text { Inventory }\end{array}$ & $\begin{array}{c}8.0 \pm 5.4 \\
(7.9 \pm 6.1)^{a}\end{array}$ & $\begin{aligned} 7.5 & \pm 5.5 \\
(6.5 & \pm 5.4)\end{aligned}$ & $(5.6 \pm 3.6)$ & $(3.321)$ & $(0.07)$ & 0.85 & 10 & 0.42 \\
\hline $\begin{array}{c}\text { Spielberger State } \\
\text { Anxiefy Scale }\end{array}$ & $\begin{array}{c}45.1 \pm 8.1 \\
(46.7 \pm 7.5)\end{array}$ & $\begin{aligned} 43.9 & \pm 9.9 \\
(45.4 & \pm 10.4)\end{aligned}$ & $(44.5 \pm 6.16)$ & $(2.126)$ & $(0.16)$ & 1.03 & 10 & 0.33 \\
\hline $\begin{array}{l}\text { Patient-Rated Anxiety } \\
\text { Scale }\end{array}$ & $\begin{array}{c}30.1 \pm 18.6 \\
(31.8 \pm 19.7)\end{array}$ & $\begin{array}{c}26.2 \pm 25.9 \\
(29.0 \pm 29.7)\end{array}$ & $(29.9 \pm 24.8)$ & (1.46) & $(0.27)$ & 1.30 & 10 & 0.22 \\
\hline \multicolumn{9}{|l|}{ Clinician-rated measures } \\
\hline $\begin{array}{l}\text { Hamilton Rating Scale } \\
\text { for Depression }\end{array}$ & $\begin{array}{c}11.0 \pm 5.6 \\
(12.0 \pm 6.2)\end{array}$ & $\begin{aligned} 12.5 & \pm 5.0 \\
(12.6 & \pm 5.9)\end{aligned}$ & $(11.1 \pm 5.4)$ & $(0.387)$ & $(0.69)$ & 1.47 & 11 & 0.15 \\
\hline $\begin{array}{l}\text { Zung Clinician-Rated } \\
\text { Anxicty Scale }\end{array}$ & $\begin{array}{c}44.1 \pm 8.9 \\
(44.9 \pm 9.8)\end{array}$ & $\begin{array}{c}44.8 \pm 11.5 \\
(44.7 \pm 12.9)\end{array}$ & $(42.4 \pm 10.9)$ & $(0.279)$ & $(0.76)$ & 0.35 & 11 & 0.73 \\
\hline Global Anxiety Rating & $\begin{aligned} 5.3 & =1.7 \\
(5.1 & \pm 1.8)\end{aligned}$ & $\begin{array}{c}4.8 \pm 1.8 \\
(4.8 \pm 1.9)\end{array}$ & $(5.0 \pm 1.9)$ & $(0.094)$ & $(0.91)$ & 0.70 & 11 & 0.50 \\
\hline $\begin{array}{l}\text { Anxious feelings } \\
\text { during previous week }\end{array}$ & $\begin{array}{l}49 \pm 31 \\
(50 \pm 31)\end{array}$ & $\begin{aligned} 3.5 & \pm 27 \\
(34 & \pm 26)\end{aligned}$ & $(41 \pm 24)$ & $(1.874)$ & $(0.19)$ & 2.39 & 11 & 0.04 \\
\hline $\begin{array}{l}\text { Panic attacks and } \\
\text { limited symptom } \\
\text { attacks in previous } \\
\text { week }\end{array}$ & $\begin{array}{l}2 \pm 2 \\
(2 \pm 1)\end{array}$ & $\begin{aligned} 2 & \pm 1 \\
(1 & \pm 1)\end{aligned}$ & $(2 \pm 1)$ & $(0.095)$ & $(0.91)$ & $\begin{array}{l}\text { Wilco } \\
\text { not }\end{array}$ & ic & \\
\hline
\end{tabular}

"One-factor repeated measures analysis of variance (ANOVA), within subjects, across treatment conditions, comparing pretreatment, treatment, and posttreatment raings, whiy for aubset of nine subjects treated with placebo before and after dipyridarnole treatment. All numbers in parentheses refer to this subset of nine subjects.

bPaired $t$-tests compared pretreatment and treatment ratings for all 12 subjects.

be excluded owing to our small sample size, we believe that this is highly unlikely, given the consistently negative findings across several different rating scales. Furthermore, although well tolerated, not a single subject elected to continue trostment with dipyridamole at the completion of the study. This is further testimony to the drug's lack of efficacy.

Why was the drug not effective in these patients? There are several possible explanations. First is the question of dose. Lacking any prior data on the use of this drug as an antianxiety agent, we chose to administer the maximal dose that we knew, based on recommended doses for thromboembolic prophylaxis, could safely be administered to humans. It is entirely possible that much higher doses of dipyridamole might have been needed to result in the indirect agonist effect that we hoped to achieve in this study.

A more legitimate concern is that the drug may not have penetrated the CNS. The ability of dipyridamole to cross the blood-brain-barrier (BBB), as measured by its appearance in cerebrospinal fluid in healthy humans following oral administration, is believed to be very poor (Roshringer-Ingelheim, data on file, written communication to the authors, 1986). Nevertheless, adenosine freely crosses the BBB, and it was hoped that adenosine reuptake, even if this were occurring outside the CNS, might still result in augmented adenosinergic neurotransmission in the brain; however, this remains to be demonstrated in animal studies. We would further suggest that when orally administered adenosine agonist drugs with demonstrated CNS activity become available, these would still be promising candidates for the treatment of anxiety disorders.

What do our findings say about an adenosinergic hypothesis of panic disorder? Clearly, the lack of efficacy of this drug does nothing to support a role for adenosinergic dysfunction as a central component of the pathophysiology of anxiety disorders; however, given the caveats with regard to dose and CNS penetrability discussed above, our findings may, unfortunately, not provide a valid test of this hypothesis. It is possible, for example, that agonist treatment may be unsuccessful because the adenosine receptors downregulate in response to chronic agonist exposure (Porter et al 1988). It is also reasonable to consider that the current adenosinergic hypothesis of panic disorder must be redefined, taking into account our growing understanding of the adennsine $A_{1}$ and $A_{2}$ receptor subtypes (Bruns of ai 1987).

In summary, our observations clearly reject an immediate role for dipyridamole in the treatment of panic and related anxiety disorders. We do believe, however, that further advances in our understanding of the role of adenosinergic neurotransmission in the pathophysiology of 
panic disorder must await the availability of adenosine subtype-specific compounds that have demonstrated CNS activity and can be safely administered to human beings.

\section{References}

Ballenger JC, Burrows GD, DuPont RL, et al (1988): Alprazolam in panic disorder and agoraphobia; efficacy in short-term treatment. Arch Gen Psychiatry 45:413-422.

Barraco RA, Cofín VL, Altman HJ, Phillis JW (1983): Central effects of adenosine analogs on locomotor activity in mice and antagonism of caffeine. Brain Res 272:392-395.

Barraco RA, El-Ridi MR, Ergenc E, Phillis JW (1991): Adenosine receptor subtypes in the brainstem mediate distinct cardiovascular response patterns. Brain Res Bull 26:59-84.

Boulenger J-P, Uhde TW (1982): Caffeine consumption and anxicty: preliminary results of a surviy comparing patients with anxiety disorders and normal controls. Psychopharmacol Bull 18:53-57.

Boulenger J.P, Patel J, Marangos PJ (1982): Effects of caffeine and theophylline on adenosine and benzodiazepine receptors in human brain. Neurosci Lett 30:161-166.

Boulenger J-P, Uhde TW, Wolff EA, et al (1984): Increased sensitivity' to caffeine in patients with panic disorders: Preliminary evidence. Arch Gen Psychiatry 41:1067-1071.

Boulenger J-P, Salem N, Marangos PJ, and Uhde TW (1987): Plasma adenosine levels: Measurement in humans and relationship to the anxiogenic effcets of caffeine. Psychiatry Res 2):247-255.

Bruns RF (1990): Structure activity relationships for adenosine antagonists. In Jacobson KA, Daly JW, Mangiello V (eds), Purines in Cellular Signalling: Targets for New Drugs. New York: Springer-Vorlag, pp 126-135.

Bruns RF, Lu GH, Pugsley TA (1987): Adenosine receptur subtypes: B inding studies. In Gerlach E, Becker BF (eds), Topics and Perspectives in Adenosine Research. New York: SpringerVerlag, pp 59-73.

Charney DS, Heninger GR, Jaflow PI (1985): Increased anxiogenic effects of caffeine in panic disorders. Arch Gen Psychiary 42:233-243.

Choi OH, Shamin MT, Padgett WL, Daly JW (1988): Caffeine and theophylline analogues: Correlation of behavioral effects
The authors wish to thank Thomas A. Mellman, M.D., and Marilla Geraci, R.N., B.S.N., for their assistance in the conduct of this study.

with activity as adenosine receptor antagonists and as phophodiesterase inhibitors. Life Sci 43:387-398.

Cofin VL, Spealman RD (1987): Behavioral and cardiovascular effects of analogs of adenosine in cynomolgus monkeys. $J$ Pharmacol Exp Ther 241:76-83.

Fredholm BB, Persson CGA (1982): Xanthine derivatives as adenosine receptor antagonists. Eur J Pharmacol 81:673676.

Fyer AJ, Endicott J, Mannuzza S, Klein DF (1985): Schedule for Affective Disorders and Schizophrenia-Lifetime Version, Modified for the Study of Anxiety Disorders (SADS-LA). New York: Anxiety Disorders Clinic, New York State Psychiatric Clinic.

Gould RJ, Murphy KMM, Katims JJ, et al (1984): Caffeine actions and adenosine. Psychopharmacol Bull 20:436-440.

Klabunde RE (1983): Dipyridamole inhibition of adenosine metabolism in human blood. Eur J Pharmacol 93:21-26.

Linden J (1991): Structure and function of Al adenosine receptors. FASEB J 5:2668-2676.

Porter NM, Radulovacki M, Green RD (1988): Desensitization of adenosine and dopamine receptors in rat brain after treatment with adenosine analogs. J Pharmacol Exp Ther 244:218225.

Snyder SH (1985): Adenosine as a neuromodulator. Annu Rev Neurosci 8:103-124.

Snyder SH, Sklar P (1984): Behavioral and molecular actions of caffeine: Focus on adenosine. J Psychiatr Res 18:91-106.

Snyder SH, Katims JJ, Annau A, Bruns RF, Daly JW (1981): Adenosine receptors and the behavioural actions of methylxanthines. Proc Nall Acad Sci USA 78:3260-3264.

Sollevi A. Ostergren J, Hjemdahl B, et al (1984): The effect of dipyridamole on plasma adenosine levels and skin microcirculation in man. Adv Exp Med Bial 165:(Pt. A):547.

Uhde TW (1990): Caffeine provocation of panic: A focus on biological mechanisms. In Ballenger JC (ed), Neurobiology of Panic Disorder. New York: Alan R. Liss, pp 219-242. 